\title{
Prospects of E-Banking Practices in Cooperative Bank of Oromia Mida Kegn Branch, Oromia Regional State, Ethiopia
}

\author{
Dr A Tamilarasu ${ }^{1} \quad$ Ato Antinafu Abera ${ }^{2}$ \\ 1.Assistant Professor, Department of Cooperatives, Ambo University- Ethiopia \\ 2. M.A., ScholarDepartment of Cooperatives, Ambo University- Ethiopia
}

\begin{abstract}
The aim of this paper is to the Prospects of Electronic banking practices in Cooperative Bank of Oromia Mida Kegn Branch, Oromia Regional State, Ethiopia. The study was conducted based on the data gathered from Cooperative Bank of Oromia Mida Kegn Branch (CBO) and from the selected respondents . Mixed research approach was used fulfill the objectives of the study. The study statistically analyzes data obtained from the survey questionnaire. The data were gathered through primary sources, the collected data were analyzed with descriptive statistics through frequency distribution and percentages, mean and standard deviation, Pearson Correlation to come up the results of data. Mean score is used to identify the highest and the lowest of the variables. Pearson's Correlation analysis is used to describe (test) independent variables and the dependent variable. The study also suggests a series of measures which could be taken by the Cooperative Bank of Oromia Mida kegn Branch and to address Prospects for the adoption of the E- banking practices in the study. It is possible for the adiotion of the e-banking practices by enhancing the awareness level of individuals, establishing a clear set of legal framework on the use of technology in banking industry, supporting banking industry by investing on telecommunication infrastructure and hiring well trained and experienced IT professionals to handle the E-Banking business competently with adequate knowledge.
\end{abstract}

Keywords: Challenges; Prospects; Electronic Banking practices ; Cooperative Bank of Oromia

DOI: $10.7176 /$ RJFA/12-13-02

Publication date:July $31^{\text {st }} 2021$

\section{Background of the Study}

Now a day's modern technology is being introduced in all fields and it is changing the world with full of innovations. In this regard, information technology is considered as the key driver for the changes to take place around the world. Due to this growth in information and communication technology, the banking industry is entering into new phenomena of unprecedented form of competition supported by modern information and communication infrastructure especially through the use of internet (Shittu, 2010).

The concepts of E-Banking become popular when the banking activities and information technology are merged. When the internet facilities enter into the banking sector, the inter-bank activities are linked through internet, the concept of "Electronic Banking or Net Banking" is also introduced. Electronic banking enables a customer to do banking transactions through the bank's website in the internet. It is more or less like bringing the bank to customer's computer, at the place and time of customer's choice. (Devamohan, 2012).

In the face of rapid expansion of electronic banking systems throughout the developed and the developing world, Ethiopia's financial sector cannot remain an exception in expanding the use of the electronic banking system. In this context, the study was made an attempt to trace the present status of E-Banking in Cooperative Bank of Oromia Mida Kegn Branch, Oromia Regional State, Ethiopia and the prospects towards the adoption of the E- banking practices in the study area.

\section{Statement of the problem}

The main driver behind electronic banking is convenience. It is available around the clock, is extremely timesaving, and is accessible from anywhere around the world. Electronic banking is very efficient, and has helped cut down a lot of costs, and in the case of virtual banks it has cut down almost all costs (Alam, 2010).

The adoption and growth of Electronic Banking is found to be very important towards creating a cashless society with its impact on bringing economic transparency, efficiency and growth. From customers' perspective, the most recognized drivers for the growth of Electronic Banking include convenience, reliability, widely availability, affordability and usefulness of the services (CBO, 2017/18).

Despite the fact that E-Banking has a lot of benefit for both banks and customers in Oromia, customers are not enjoying with the technological advancement in banking sector which is newly emerging. Banking operation is still under developed backed by low level of infrastructural development, lack of suitable legal and regulatory framework, high rates of illiteracy, frequent power interruption and security issues . Moreover, E-Banking is a new technology in Ethiopia which needs a lot of effort and resources to be easily adopted by customers (Yitbarek, 2013).

According to Kumaga (2010), low level of internet penetration and poorly developed telecommunication 
infrastructure impede smooth development and improvements in E-commerce in developing countries. In this regard, Hence, in order to help banks to improve E-Banking adoption for their customers, it is necessary to examine prospects to adopt E-Banking service of Cooperative Bank of Oromia Mida Kegn Branch.

\section{Objective of the study}

To assess the prospects of E-Banking in CBO Mida Kegn Branch.

\section{LITERATURE REVIEWS}

\section{Origin of E- Banking}

The use of electronic communication in finance goes back much further than the 1970s. As long ago as 1918, the payments between banks used to be settled electronically over the telegraph. This use of electronic communications in payments systems has steadily increased over time. Now virtually all large payments between banks and corporations are done electronically. Financial services industry has removed the boundaries between different financial institutions, enabling new financial products and services to appear and making the existing ones available in different packages (Turban, 2012).

E-Banking can be also defined as a variety of platforms such as internet banking or (online banking), TVbased banking, mobile phone banking, and PC (Personal Computer) Banking (or offline banking) whereby customers access these services using an intelligent electronic device, like PC, Personal Digital Assistant (PDA), Automated Teller Machine (ATM), Point of Sale (POS), kiosk, or Touch Tone Telephone (Alagheband, 2006).

\section{Mobile Banking}

Mobile Banking can be defined as an occurrence when customers access a bank's networks using cellular phones, pagers, personal digital assistants, or similar devices through telecommunication wireless networks (Segun, 2011). It means performing banking activities which primarily consists of opening and maintaining mobile/regular accounts and accepting deposits; furthermore, it includes performing fund transfer or cash-in and cash-out services using mobile devices (NBE Directive, FIS-01-2012).

The Ethiopian banking industry is consisting of 3 public and 21 private sector banks under the control of National Bank of Ethiopia (NBE), the central bank of the country. The NBE is having full control over the cooperative banks of the country. The Cooperative Bank of Oromia (CBO), a public sector bank, is playing major role in the industry with 360 branches. (Muche 2010)

\section{Prospects of E-Banking}

Increasing Internet Users \& Computer Literacy

To use internet banking it is very important or initial requirement that people should have knowledge about internet technology so that they can easily adopt the internet banking services. The fast increasing internet users in Oromia can be a very big opportunity and banking industry should in cash. This opportunity to attract more internet users to adopt internet banking services.

\section{Initiatives Taken By Government Agencies for Financial Literacy}

Financial literacy and education play a crucial role in financial inclusion, and inclusive growth. A study reported that there is significant impact of financial literacy on use of internet banking, If customers are not financially educated they will simply avoid using new online services and not change their traditional way of banking, thus banks will not be able to convert users into their new online banking strategies.

\section{Competitive Advantage}

The benefit of adopting E-Banking provides a competitive advantage to the banks over other players. The Implementation of E-Banking is beneficial for bank in many ways as it reduces cost to banks, improves customer relation increases the geographical reach of the bank, etc. The benefits of E-Banking have become prospects for the banks to manage their banking business in a better way.

\section{The gap of the study}

As reviews reviewed from many researchers studied, many of them were studied factors determining for the adoption of E- banking services, but still little studies are available in Ethiopia also but there is no study available in the study area, study unit related to the Prospects for the E- banking practices in cooperative bank of Oromia Mida Kegn Branch, Oromia Regional State, Ethiopia

\section{Research Design}

To attain the intended objective of this study, Descriptive Research Design was employed. It is descriptive research design because it aims to describe, contrast and analyze the problem identified and to describe the 
relationship between the E-Banking variables and customer satisfaction and how these dimensions affect customer satisfaction.

\section{Types and Sources of Data}

In this study, both primary and secondary data sources were employed. The data type of the study was crosssectional data since the Research on the challenges and prospects of E- Banking practices in the case of Cooperative Bank of Oromia MidaKegn Branch. The data required for the study is obtained from primary and secondary sources.

\section{Primary Data Source}

Primary data source is required in order to get first-hand information with respect to the study under consideration. Primary data was collected from the sample customers' respondents by using questionnaire. The structured questionnaires were developed in English.

\section{Data Collection Techniques}

Two types of instruments were used in this study in order to collect both qualitative (by interviews) and quantitative data (by questionnaires). The primary data was collected through questionnaire. The questionnaire was administered through trained data collectors using interview type. With regard to the questionnaire, the questions are both open ended and close ended.

\section{Sampling Techniques}

The method of sampling techniques that was employed in this study is Simple Random Sampling. Because it is chosen in order to avoid bias. In Simple Random Sampling by its nature, each element in the population has an equal chance of being included in the sample. The sample item comprised of the customers of the Bank and Bank officials in the study unit and in the study area.

\section{Populations of the Study}

The target populations of the study area are: - Bank staffs16, Bank's customers 13,931 and the total are 13,947. They are 10,695 customers are using electronic banking and 3,252 are non-using Electronic Banking. The researcher, study only the customers who uses Electronic Banking only.

\section{Method of sample size determination}

Multi stage sampling was used. The Cooperative Bank of Oromia has more than 360 Branches and Midakegn Branch is one of the Nekemte districts of CBO that has 10 branches under its domain. Out of these 360 branches, the study was conducted in Mida Kegn Branch and 154 customers were also selected on Simple Random Sampling Method because of large numbers of CBO's customers.

For the purpose of this study, based on population size, sampling error (the level of precision) the confidence level, finance and time available for the researcher, sample size was determined by Yamane formula in a scientific way. $\quad \mathrm{N}=10,695 \quad \mathrm{e}=0.08 \quad \mathrm{Z}=92 \%$

Hence, following formula is used.

$$
n=\frac{N}{1+N(e)^{2}}=\frac{10,695}{1+10,695(0.08)^{2}}=\underline{154}
$$

Where $N$ is the population size, $\mathrm{n}$ is sample size, $\mathrm{Z}$ is the confidence level and $e$ is the level of precision or sampling error. Since in a social science, $1 \%-10 \%$ of errors are acceptable, for the purpose of this study, the researcher was accept $8 \%$ of error due to of lack time and fund to collect data from large sample(Admas et al,2007).

\section{Method of Data Analyzing}

The data that was gathering through primary method was summarizing using descriptive statistics through frequency distribution and percentages, mean and standard deviation, Pearson Correlation to come up the analyses of data. Mean score is used to identify the highest and the lowest of the variables. Pearson's Correlation analysis is used to describe the magnitude/degree of association between independent variables and the dependent variable.

In order to meet the stated research objectives, the collected data is analyzed based on the nature of the objective. Accordingly, the data collected via questionnaires is analyzed with descriptive statistics using Statistical Package for the Social Sciences (SPSS) V. 20.0. 
Table-1- Gender of the Respondents

\begin{tabular}{|c|c|c|c|}
\hline Gender & Frequency & Valid Percent & Cumulative Percent \\
\hline Male & 126 & 81.8 & 81.8 \\
\hline Female & 28 & 18.2 & 100.0 \\
\hline Total & $\mathbf{1 5 4}$ & $\mathbf{1 0 0 . 0}$ & \\
\hline
\end{tabular}

Source- Primary Data- 2019

It is understood from the above Table- 1 - that the majority of the respondents $n=126$ ( 81.8 percent) belonged to the male category and the rest of them $n=28$ (18.2 percent) belonged to the female category.

Table-2- Occupational Level of the Respondents

\begin{tabular}{|l|c|c|c|}
\hline Occupations & Frequency & Valid Percent & Cumulative Percent \\
\hline Government Employee & 66 & 42.9 & 42.9 \\
\hline Private Employee & 18 & 11.7 & 54.6 \\
\hline Business Men & 25 & 16.2 & 70.8 \\
\hline Daily Labor & 19 & 12.3 & 83.1 \\
\hline Students Total & 26 & 16.9 & 100.0 \\
\hline \multicolumn{1}{|l|}{} & $\mathbf{1 0 0}$ & \\
\hline
\end{tabular}

Source- Primary Data- 2019

It is witnessed from the above table -2- regarding the occupational level of the respondents, it showed that the majority of the respondents were belonged to the government employee category $n=66$ ( 42.9 percent), considerable percent $n=26$ ( 16.9 percent)of the respondents belonged to the students category of the occupations, it is also observed from the table that $n=25$ (16.2 percent) were businessmen and the rest of them were belonged to the occupational level of daily labor and the private employees

Table-3- Prospects of Adoption of E-Banking Practices

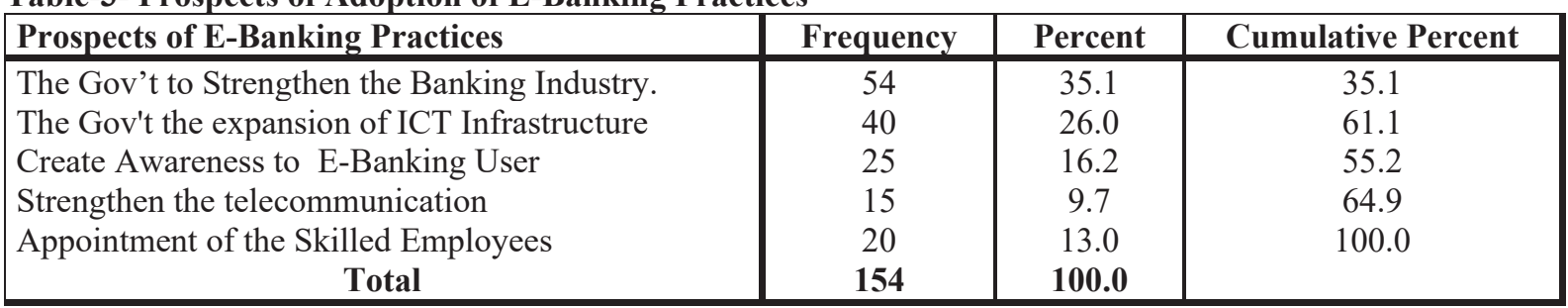

Source- Primary Data- 2019

The above table 3 shows the Prospects of Adoption of E-Banking infrastructure in CBO majority of the respondents $n=54(35.1 \%)$ replies that they used E-Banking for the government has to strengthen the banking industry and $n=40$ (26.0 percent) the respondents opinion that the government has to expand the ICT infrastructure in the country. And also the bank has to create the awareness to the bank employees and customers for the usages of E- Banking Services.

Table 4. Paired Samples Correlations Test

\begin{tabular}{|c|c|c|c|c|}
\hline \multicolumn{2}{|c|}{ Paired Samples Correlations } & $\mathbf{N}$ & Correlation & Sig. \\
\hline Pair 1 & Prospects of E-banking practices\& Security of E-Banking Practices & 154 & .552 & .000 \\
\hline Pair 2 & $\begin{array}{l}\text { Prospects of E-banking practices\& Role of Gov"t to Adopt } \\
\text { Technology }\end{array}$ & 154 & .744 & .000 \\
\hline Pair 3 & Prospects of E-banking Practices Technological Factor & 154 & .817 & .000 \\
\hline Pair 4 & Prospects of E-banking practices and Organizational Factor & 154 & .680 & .000 \\
\hline Pair 5 & Prospects of E-banking practices and Environmental Factor & 154 & .497 & .000 \\
\hline Pair 6 & $\begin{array}{l}\text { Prospects of E-banking practices and Lack of Adequate ICT } \\
\text { Infrastructure }\end{array}$ & 154 & .658 & .000 \\
\hline Pair 7 & Prospects of E-banking practices\& Environmental Factor & 154 & .820 & .000 \\
\hline
\end{tabular}

Source- Primary Data- 2019.

Based on the result of paired sample T-test correlation stated on table 4 The mean difference of prospects of E-Banking practices \& Security of E-Banking service implementation of CBO is estimated to be a mean value of .552 indicated that the prospects of E-banking practices after the implementation of the Security of E-Banking service exceeds by 0.055 percent that of Environmental Factor on the implementation of E-Banking the service.

Since the $P$ value (0.00) is less than the defined level of significance $(0.05)$ there is statistically significance difference on the prospects of E-Banking practices between Security of E-Banking and Environmental Factor after the implementation of E-Banking services. In other words a mean difference of 0.055 is not strong enough to make a difference on prospects of E-Banking practices performance of $\mathrm{CBO}$ in the study area.

The mean difference of prospects of E-Banking practices of E-Banking services implementation of CBO is 
estimated to be 0.323 indicted that the prospects of E-Banking practices to the implementation of the services is not that much hindered to apply into the system. Since the P value $(0.001)$ is less than the defined level of significance (0.05) there is statistically significance difference on the prospects of E-Banking practices (dependent variable) and independent variable on the implementation of E-Banking services.

Table 5: Paired Samples T-Test

\begin{tabular}{|c|c|c|c|c|c|c|c|c|c|}
\hline \multicolumn{2}{|c|}{ Paired Samples Test } & \multirow{2}{*}{\multicolumn{5}{|c|}{ Paired Differences }} & \multirow[t]{4}{*}{$\mathrm{T}$} & \multirow[t]{4}{*}{ Df } & \multirow{4}{*}{$\begin{array}{l}\text { Sig. (2- } \\
\text { tailed) }\end{array}$} \\
\hline & & & & & & & & & \\
\hline & & \multirow{2}{*}{ Mean } & \multirow{2}{*}{$\mathrm{SD}$} & \multirow{2}{*}{$\begin{array}{c}\text { Std. E } \\
M\end{array}$} & \multicolumn{2}{|c|}{$\begin{array}{l}95 \% \text { Confidence } \\
\text { Interval of the } \\
\text { Difference } \\
\end{array}$} & & & \\
\hline & & & & & Lower & Upper & & & \\
\hline $\begin{array}{l}\text { Pair } \\
1\end{array}$ & $\begin{array}{l}\text { Prospects of E-banking } \\
\text { practices - Security of E- } \\
\text { banking }\end{array}$ & $\begin{array}{c}- \\
1.41558\end{array}$ & .75582 & .06091 & -1.53591 & -1.29526 & $23 . \overline{2} 42$ & 154 & .000 \\
\hline $\begin{array}{l}\text { Pair } \\
2\end{array}$ & $\begin{array}{l}\text { Prospects of E-banking } \\
\text { practices - Role of gov't to } \\
\text { adopt technology }\end{array}$ & .04545 & .78666 & .06339 & -.07978 & .17069 & .717 & 154 & .474 \\
\hline $\begin{array}{l}\text { Pair } \\
3\end{array}$ & $\begin{array}{l}\text { Challenges and Prospects } \\
\text { of E-banking practices - } \\
\text { Technological Factor }\end{array}$ & -.14286 & 1.04430 & .08415 & -.30911 & .02339 & -1.698 & 154 & .092 \\
\hline $\begin{array}{l}\text { Pair } \\
4\end{array}$ & $\begin{array}{l}\text { Prospects of E-banking } \\
\text { practices - Organizational } \\
\text { Factor }\end{array}$ & -.77273 & 1.05113 & .08470 & -.94006 & -.60539 & -9.123 & 154 & .000 \\
\hline $\begin{array}{l}\text { Pair } \\
5\end{array}$ & $\begin{array}{l}\text { Prospects of E-banking } \\
\text { practices - Environmental } \\
\text { Factor } \\
\text { Prospects of E-banking }\end{array}$ & .59091 & .54369 & .04381 & .50435 & .67746 & 13.487 & 154 & .000 \\
\hline $\begin{array}{l}\text { Pair } \\
6\end{array}$ & $\begin{array}{l}\text { practices - Lack of } \\
\text { Adequate ICT } \\
\text { Infrastructure }\end{array}$ & -.17532 & .62761 & .05057 & -.27524 & -.07541 & -3.467 & 154 & .001 \\
\hline $\begin{array}{l}\text { Pair } \\
7\end{array}$ & $\begin{array}{l}\text { Prospects of E-banking } \\
\text { practices - Environmental } \\
\text { Factor }\end{array}$ & -.27273 & .81065 & .06532 & -.40178 & -.14367 & -4.175 & 154 & .000 \\
\hline
\end{tabular}

Source- Primary Data- 2019

Based on the result of paired sample T-test stated on the above table. The mean on the prospects of EBanking practices \& Security of E-Banking service implementation of CBO is estimated to be a mean value of .552 indicated that the prospects of E-Banking practices after the implementation of the Security of EBanking service exceeds by 0.055 percent that of Environmental Factor on the implementation of E-Banking the service.

Since the $\mathrm{P}$ value (0.00) is less than the defined level of significance (0.05) there is statistically significance difference on Challenges and prospects of E-Banking practices between Security of E-Banking and Environmental Factor after the implementation of E-Banking services. In other words a mean difference of 0.055 is not strong enough to make a difference on prospects of E-Banking practices performance of CBO in the study area.

\section{Recommendations:}

On the basis of the above interpretation, findings the following suggestion were made for the adoption of Ebanking practices in the study units

It is recommended that the government of Ethiopia and its concern body has to frame a strong banking regulations and the proclamation for the strengthen of the e- banking practices in all the banks since this the technical scenario, it is must for the sustainable development of the banking sectors in the developing county.

Since the ICT (Information, Communication and Technology) is the heart of the technology all the sectors and in almost all counties are using ICT generally particularly in the service sectors, hence it is recommended that the government of Ethiopia has to make strengthen of the ICT in the rural area and among the banking industry for the adoption of the e- banking practices in the rural area and the study area also.

It is highly recommended that even the all the customers have to be created awareness for the use of the ebanking services in the study unit and in the study area also, the banking officials and the government has to create the awareness program to the existing and the new customers' towards the benefits of the E- Banking services. 
The government and the bank has to appoint the skilled employees for the banking sectors, particularly in the technology area, and the same have to provide the training for the employees of the banks for the speed services through the e-banking

It is suggested that the government has to turn their view for the development of proper electricity, network and the strengthen the telecommunication sectors for the adoption of the E- Baking services in the country for the sustainable development of the banking industry in general and the country in particular.

\section{References:}

Adams, J., Khan, H. T., Raeside, R., \& White, D. (2007). Research Methods for Graduate Business and Social Science Students . California: Sage

Alagheband,(2006.)Adoption of electronic banking services by Iranian Customers, MA thesis,Lulea University of Technology.

Alam N. (2010). Challenges Faced by Sudanese Banks in Implementing Online Banking: Bankers' Perception, Journal of Internet Banking and Commerce, vol. 15, no.2, pp.2.

Devamohan, A (2012).Lecture Note on E-Banking -Problems and Prospects in Ethiopia, Jimma University, Unpublished document.

Kumaga, D. (2010). The challenges of implementing Electronic Payment Systems - The Case of Ghana's Ezwich Payment System. Unpublished

Muche, B. (2010). Assessment of the Prospects and Challenges for the Adoption of E-Banking Service in Ethiopia. Mekelle, Ethiopia: Mekelle University.

National Bank of Ethiopia, (2012, November).Financial Sector in Ethiopia: NBE Birritu Quarterly Magazine, No 112, Addis Ababa, Master Printing Press.

Shittu, O. (2010). The Impact of Electronic Banking in Nigeria Banking System: Critical Appraisal of Unity Bank PLC. Ladoke Akintola University of Technology, Ogbomoso, Nigeria.

Turban, E. (2002).Electronic Commerce a Managerial Perspective. Prentice Hall, U.S.A

YitberekZeden, (2013). Online digital payment system a thesis submitted to Addis Ababa University assessed on www. aau.edu.et. 